\title{
The ethics of conditional fee arrangements
}

A report produced by a Society for Advanced Legal Studies working group in January 2001 considered in detail the ethical implications raised by conditional fee arrangements. In the first article, Richard Moorhead and Avrom Sherr, both members of the group, put forward their views on CFAs. A further two pieces commenting on the report have been contributed by Martyn Day, of Leigh Day \& Co, and Kerry Underwood of
Underwood \& Co. Kerry Underwood is well known as an enthusiastic supporter of conditional fees, and is critical of the SALS report.

Neither Martyn Day nor Kerry Underwood was a member of the working group, although both attended the launch of the report on 31 January. The views expressed by both authors are their own. A copy of the executive summary of the report is contained below.

\section{Report of the SALS Working Party on the Ethics of Conditional Fee Arrangements: Executive Summary}

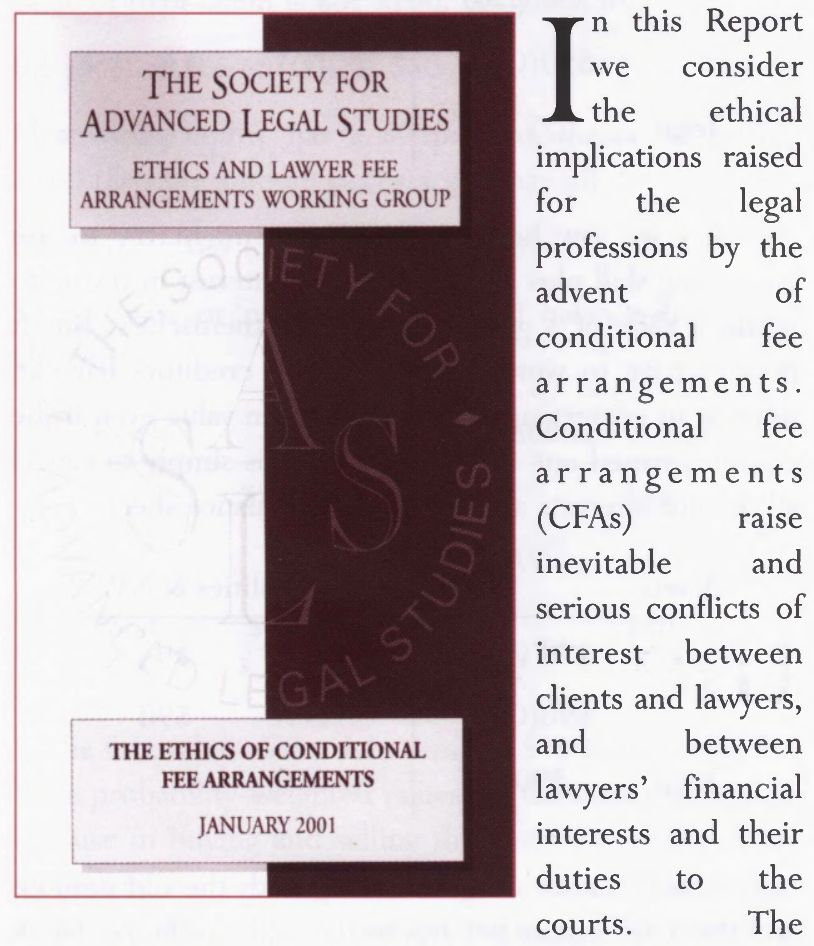

existence of lawyers' major financial interests in the outcome of cases, as a result of CFAs, will heighten preexisting tensions in the lawyer-client relationship, and create new conflicts of interest. Furthermore, and crucially, the financial interests of insurance companies, which will now occupy a central role on both sides in legal actions, will have a profound impact on access to justice and the ethics of practice.

The Report is not a challenge to the introduction of CFAs or government policy on access to justice. Rather, we examine in the Report areas of sometimes acute ethical difficulty and, where it is possible to do so, suggest what can be done to ameliorate the problems.

In this Report we first explain the policy and statutory framework for CFAs as the context for the Report's proposals (Chapter 2). We then analyse the ethical problems, which the introduction of this statutory framework will be likely to create, and we make recommendations for changes to professional codes of conduct, and for training and research, which in our judgment are appropriate to ameliorate the identified ethical problems. We do so in relation to solicitors (Chapter 3) and to barristers (Chapter 4), and consider the impact on the judges (Chapter 5).

A full summary of our recommendations is set out in Chapter 6. Our recommendations include:

- The role and conduct of insurance companies in the litigation process should be subjected to research and independent scrutiny.

- Proper training in risk assessment should be given to the legal professions.

- A firm cap of the total costs at a particular percentage of the damages should be applied compulsorily to all but the most exceptional cases (with more consumer protection for dealing with exceptional cases).

- A compulsory 'period of contemplation' should be required between the explanation of a draft CFA and the client being asked to sign, except in cases of urgency. The benefit of such a period could be strengthened by lending the client a video (prepared by the Community Legal Service) explaining the ins and outs of CFAs.

- Normally 'success' and 'win' should be defined (and cap-measured) under claimant CFAs in terms of damages recovered, rather than damages awarded, to ensure transparency and fairness to consumers.

- Better rules about how and when lawyers can recover costs from their clients under CFAs should be laid down.

- Requirements should be placed on solicitors and barristers when taking witness statements to give 
certificates that the statements accurately represent the evidence of the witness/expert.

- It should be a rule of court that no expert or other witness is permitted to be paid on a speculative, contingent or conditional fee basis. A code of guidance will not suffice.

- Any undertaking which impairs the ability of members of the public to gain access to a particular solicitor or solicitors should be submitted to the court for the court's approval at the cost of the party seeking the undertaking. Rules of court governing such applications should emphasise the potential detrimental effect on access to justice and the court's obligations under Article 6 of the ECHR.

- The Law Society's Practice Rules should make clear that a solicitor's duty to their client under Practice Rule 1 puts the solicitor in a situation of conflict with their client if the solicitor is aware that insurance they advise the client to take out is either unnecessary or unnecessarily expensive.

- There should be written into the Bar's Code of Conduct stronger provisions requiring barristers always to act in accordance with their client's interest, and not the personal interests of the barristers. These provisions should be carefully drafted so that they can be used as the basis for charges of professional misconduct if evidence that they have not been complied with is forthcoming.
- Intra-chambers conflict problems should be covered by specific provisions in the Bar's Code of Conduct, and not be left merely to the Ethical Guidance provided by the Bar Council.

- Judges should play their appropriate part in maintaining and raising ethical standards in the legal professions. (c)

The working party members were: Geoffrey Bindman, senior partner, Bindman \& Partners; Ben Emmerson QC; Max Findlay, legal writer \& journalist; Matthias Kilian, Senior Research Fellow, Institute of Employment \& Business Law, Cologne; Jennifer Levin, Foundation professor of Law, University of Wales; The Hon Mr Justice Lightman; David Mackie QC; Bill Montague, partner, Dexter Montague \& Partners; Richard Moorhead, Senior Research Fellow, IALS;

Richard O'Dair, senior lecturer in law, University College, London; Andrew Phillips, partner, Bates Wells \& Braithwaite; Professor Avrom Sherr, Woolf Professor of Legal Education, IALS; Dr Hilary Sommerlad, solicitor, senior lecturer in law, Leeds Metropolitan University; Richard Southwell QC; Stella Yarrow, Research Fellow, School of Law, University of Westminster.

Copies of the Society for Advanced Legal Studies Report on The Ethics of Conditional Fees can be obtained, price $£ 30$ ( 220 for SALS members) from Tracy Paradise, Secretary of SALS, on 02078625866.

\section{Midnight in the garden of the CFA people}

by Richard Moorhead and Avrom Sherr

$\mathrm{T}$ There is a lot riding on the success of conditional fee agreements (CFAs). They are a central plank in the government's legal services policy and, for many in the profession they offer the opportunity to reclaim practices damaged by the erosion and removal of legal aid. The Law Society has endorsed a conditional fee agreement referral scheme backed by insurance and there are numerous insurance companies selling conditional fee agreement related policies. More fundamentally, conditional fee agreements currently represent the best hope for the general public of gaining access to justice. Little surprise then that a report, produced by a working group of the Society of Advanced Legal Studies (SALS), The Ethics of Conditional Fee Arrangements, should provoke a strong reaction from conditional fee agreement lawyers (see 'Conditional Fee Agreements', New Law Journal, 9 February 2001).

All fee arrangements can lead to conflicts of interest, and these problems must be kept in mind in assessing the pros and cons of conditional fee agreements. Similarly, the working party was well aware of the changes introduced by the Access to Justice Act 1999; changes fully described in Chapter 2 of the report, which seek to reduce the exposure of clients to costs risks inherent in CFAs. It is understandable that government and some practitioners, with so much invested in the success of the scheme, would claim that the Access to Justice Act 1999 provides an answer to all of the problems raised by conditional fee 